\title{
Attitude Toward Khilafah Establishment:Causal Model of Muslim Fundamentalist Groups in Indonesia
}

\author{
Tutut Chusniyah \\ Department of Psychology, Universitas Negeri Malang, Indonesia
}

\begin{abstract}
Some Islamic groups think that Islam should be the foundation of the state, and that the system/form of state compatible with Islam is khilafah (an Islamic state encompassing the whole world) and enforcing sharia (Islamic laws) as the constitution. This study aims to test theoretical model about attitude toward khilafah establishment (political attitude) in three Islamic fundamentalist groups. Based on social identity theory, system justification theory and social cognitive motivation approach, this study tries to understand how psychological needs (thee need of uncertainty avoidance and the need of threat management), Islamic ideologies (salafi ideology and daula Islam ideology), and group identification influence attitude toward khilafah establishment and sharia enforcement. Analyses of data from 384 members of JAT (Jamaah Anshoru Tauhid), MMI (Majelis Mujahidin Indonesia) and HTI (Hizbut Tahrir Indonesia) who participated in the research showed a fit in each group between the proposed model and data. Each group showed variability in strength of structural relationshop between variables. Results of this study give theoretical and empirical implications about political attitudes of spme Islamic fundamentalist groups in Indonesia.
\end{abstract}

Keywords: need of uncertainty avoidance, need of threat management, salafi ideology, daula Islam ideology, in-group identification, political attitude

\section{INTRODUCTION}

Since the preparation of independence, Muslim communities in Indonesia had different political views about the nation-state form and democracy. The majority of Muslims in Indonesia are moderate Muslims, who do not see Islam and democracy as a contradiction, so they accept and support democracy (Ashour, 2009; Effendy, 1998; Madrid, 2001; Mujani, 2003). Whereas some other Muslims, like in HTI (Hizbut Tahrir Indonesia), MMI (Majelis Mujahidin Indonesia) and JAT (Jamaah Anshoru Tauhid) groups, think that the state and democracy are contradicting Islamic beliefs (Effendy, 1998; Sheridan, 2006), so that the establishment of khilafah and sharia laws enforcement as the state constitution must be fought for. Muslim groups who refuse democracy and fight for khilafa-sharia are widely known in Indonesia as political Islam, which conceptualize Islam not just as a religion but also a political ideology. For more than four decades, the government - both in the Old Order and the New Order regime - had been trying to tame and weaken these groups; 1977 and 1978 were the year of confrontation between them and the military government of President Soeharto.

At the end of the New Order, various political Islamic movements that did not have room to grow during the Old Order and New Order regime started to appear (Hasan, 2008). Their aim was to establish an Islamic sociopolitical system (Moaddel, 2008), by applying and enforcing sharia in all aspects of life (Zada, 2003), therefore they wanted to change the nation-state and democracy system that were applied in Indonesia. Understanding this khilafa-sharia movement is crucial, because it often turns into problem when its supporters show intolerant behavior (An-Naim, 2003), treason and terrorism (Ben Ali, 2006; Kramer, 2003; Rapoport, 1998). For example the groups FPI (Front Pembela Islam or Islamic Defenders Front) and MMI who conducted raids to places with prostitution, gambling and alcoholic drinks (Purnomo, 2004), and Lasykar Jihad's involvement in religious conflicts in Ambon, Maluku. Some JAT members were even involved in suicide bombing in Mapolresta Cirebon Complex, West Java, on 15 April 2011; suicide bombing in Bethel Injil Sepenuh Church in Kepunton, Solo, on 25 September 2011; bombing in Senolo village, Bima, West Nusa Tenggara on 11 July 2011; and even until now, Abu Bakar Baasyir (JAT's leader) is still in Nusakambangan Prison because of military training of a terrorism group in Aceh (Kompas.com, retrieved 2011).

This study is important for social psychology, to investigate the power of psychology behind the political attitudes and behavior of society (see Jost et al., 2003a). This study is a theoretical and empirical effort in criticizing political psychology theory about political attitude, to understand and explain the motives of political Islamic groups who want to change the democracy in Indonesia to khilafa-sharia system, taking into account some psychological aspects like needs, ideology and group psychology.

System justification theory (Jost et al., 2004; Jost \& Hunyady, 2005), explains that political attitude of an individual or group who supports or is against the status quo (prevailing socio-political system), is related to 
the core dimension of conservative political ideology which refuses change, while the core dimension of liberal political ideology is to encourage change. According to this theory, individual or group with conservative political ideology supports the status quo; whereas individual or group with liberal political ideology wants to change the status quo. Furthermore, Jost et al. (2008) stated that the motives of individuals and groups with conservative ideology in maintaining the prevailing social system are caused by the need of uncertainty avoidance and the need of threat management. The conservative political ideology will help inividuals and groups in reducing uncertainty, fear, anxiety and feelings of being threatened (Jost et al., 2003b).

These two psychological needs, of uncertainty avoidance and threat management, even drive individuals or groups to rationalize economic and social inequality, and justify the system and existing social strata (Jost \& Hunyady, 2005; Jost et al., 2008, Thorisdottir et al., 2009). But system justification theory cannot explain why extreme right-wing movement with conservative ideology, like khilafa-sharia establishment movement in Indonesia, wants to change democracy (the status quo) instead.

Previous research (Chusniyah, 2012) revealed that the political attitude of Islamic groups to establish khilafa-sharia was not because of political ideology (liberal-conservative), as stated by Jost's system justification theory (Jost \& Banaji, 1998), but it was influenced by religious ideology (Ben Ali, 2006; Golose, 2010; Ramakrishna, 2009; Kruglanski \& Fishman, 2009; Muluk et al., 2010; Unger, 2007), that is, salafi (the belief to purify religion and practice Islam like the salaf (the original teachings in the era of the Prophet Muhammad and the salaf) and daula Islam ideology (the belief to establish Islamic state), driven by the need to avoid uncertainty and to manage threat (Jost, 2006; Jost et al., 2003; Thorisdottir et al., 2009), and commitment to these ideologies influenced identification levels to ingroup.

Salafi ideology appears because of Islamic groups' need of uncertainty avoidance that raises categorical views (Frenkel-Brunswik, 1947), which divide the world into two: muslims and infidels. This psychological need drives individuals to purify Islam and believe that muslims have to go back to the original teachings in the era of the Prophet Muhammad and the salaf (Esposito \& Voll, 2001; Frey, 2007; Sageman, 2004). The stronger the need of uncertainty avoidance in Islamic groups, the stronger the commitment to salafi ideology.

The state of the world today is also considered a threat to the original teachings of Prophet Muhammad (Sageman, 2004). The need of threat management in Islamic groups drives them to maintain and protect their religious belief as a reaction to changes in society at this time (Frey, 2007). The changing condition of the world today is seen as a threat to religious values, and this condition can only be fixed by daula Islam (Akbar, 2002). The need of threat management drives Islamic groups to hold on to daula Islam ideology. Therefore, every muslim has the obligation to participate in building an Islamic state and society (Esposito \& Voll, 2001), and to achieve this goal they seek political power (An-Naim, 2004). The stronger the need of threat management in Islamic groups, the stronger the commitment to daula Islam ideology.

In psychology, ideology is defined as an organization of opinions, attitudes, values, beliefs, way of thinking about man and society (Adorno, 1950), institutionalized or shared with others, deriving from external authority and internalized in groups (Rokeach, 1968), aiming to unify thoughts and actions of the members (Kerlinger, 1984). Daula Islam ideology is used by the leaders to build the group, so that the actions of its members can be regulated in order to achieve the goal in changing democracy and establish khilafa-sharia in Indonesia (Almond et al., 2003). Belief and commitment of the members to daula Islam ideology is spread intensively in the group (Sageman, 2004; Ramleth, 2001). This intense collective indentification will build commitment to group, integrity, and cohesiveness to ideology. Daula Islam ideology is a group characteristic that's dispersed collectively, to facilitate the development of social identity and develop a strong attachment to internal group (Lane, 1999). Therefore, the stronger the commitment of group members to daula Islam ideology, the stronger the attachment to the group.

\section{METHOD}

This is a non-experimental study using survey to members of groups supporting the idea of $\boldsymbol{k h i l a f a - s h a r i a}$ establishment, that is, MMI, JAT, and HTI.

\subsection{Research Questions}

This study is a follow-up research that aims to answer these questions:

2.1.1. Is there a fit between research data in each group (HTI, JAT and MMI) and theoretical model of need of uncertainty avoidance, need of threat management, salafi ideology, daula Islam ideology, and group identification in influencing attitude of khilafa-sharia establishment?

2.1.2. How big is the influence of the need of uncertainty avoidance, need of threat management, salafi ideology, daula Islam ideology, and group identification on the attitude of khilafa-sharia establishment in each group (HTI, JAT and MMI)? 


\subsection{Hypothesis For Each Group: HTI, JAT, and MMI}

Structural model hypothesis (major hypothesis) that will be tested in this study is the attitude of khilafa-sharia influenced by the need of uncertainty avoidance, the need of threat management, salafi ideology, daula Islam ideology, and group identification in HTI, JAT, and MMI. While the structural relationships between research variables (minor hypothesis) are hypothesized as follows: H1-The higher the need of uncertainty avoidance, the higher salafi ideology in individuals. H2-The higher the need of threat management, the higher daula Islam ideology in individuals. H3-The higher the salafi ideology, the higher daula Islam ideology in individuals. H4-The higher daula Islam ideology, the higher group identification levels. H5-The higher group identification, the higher attitude of khilafa-sharia in individuals. Figure 1 below shows model of structural relationship between variables in khilafa-sharia establishment model that will be tested in this study.

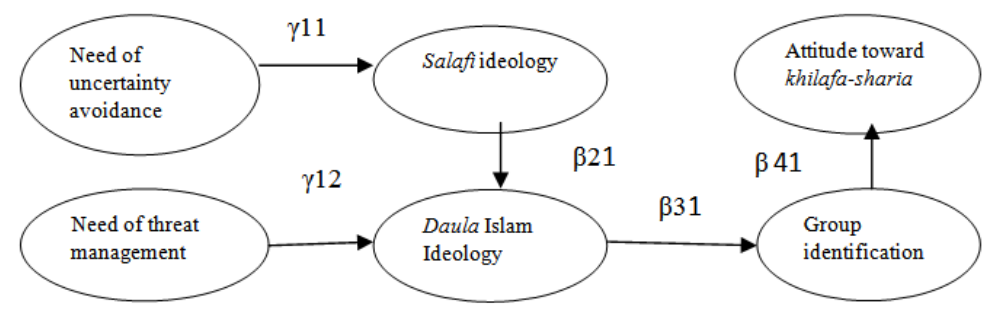

Fig. 1. Structural model of attitude toward khilafa-sharia establishment in HTI, JAT, MMI

\subsection{Research Instruments}

The instruments/scales used in this study were tested for validity and reliability beforehand, so that it can describe the actual sample characteristics. Validity of scale is the accuracy of measuring instruments/scale, while reliability shows accuracy and stability of a scale in measuring something (Kerlinger, 2000). Validity and reliability of scale were obtained by testing procedure and confirmatory factor analysis. The test for 4 Likert scale that would be used in this study was conducted with 30 respondents who shared the same criteria with the real subjects of the research. Operational definition and scale of the variables in this study are as follows:

\subsubsection{Endogen Variable}

a. Khilafa-sharia establishment (KSE): Individual preference to agree or disagree in changing the system from democracy to khilafa-sharia in Indonesia, measured with khalifa-sharia establishment scale. Example: "the democratic system in Indonesia has to be changed to khilafa-sharia system." This scale was developed after a process of elicitation, consisting of two items.

b. Group identification (GI): The level of individual's identification to group, measured with group identification scale, consisting of five items (Cadinu \& Reggiori, 2002), for example: "Being a member of HTI/MMI/JAT influenced my lifestyle and way of thinking"; and loyalty to leader scale, for example: "I submit to and obey the rules and command of the leader of HTI/MMI/JAT". This scale was developed after a process of elicitation, consisting of five items and one omitted item.

c. Salafi ideology (SI): The level of individuals' belief in practicing Islam purely according to the teachings of the Prophet and the salaf, measured with salafi ideology scale that was developed after a process of elicitation, consisting of six items, for example: "I believe Islam will reign supreme if we live according to the teachings at the time of the Prophet and the salaf."

d. Daula Islam ideology (DII): The level of individuals' belief in the importance of the power and establishment of an Islamic state, measured with daula Islam ideology scale that was developed after a process of elicitation, consisting of four items, for example: "I believe in Islam as the religion (din) and state (daula), because power system is a very important key in Islam."

\subsubsection{Exogen Variable}

a. The need of uncertainty avoidance (NUA): The level of individuals' need to avoid uncertain and ambiguous situation, measured with openness to experience scale from Big-Five (McCrae, 1996). Following Kenny's (1979) and Jost et al.'s (2008) recommendation to pick three to four items per latent variable, we then chose four items, for example: "I like surprises and always looking for new activities to do", measured with order scale from Big-Five, consisting of four items, for example: "I work according to my plan", and measured with 4-items scale of intolerance to ambiguity (Frenkel-Brunswik, 1947). 
b. The need of threat management (NTM): the level of individual's need to manage threat from the system and threat from the world as a dangerous place, measured with system threat scale that was developed after a process of elicitation, consisting of four items, for example: "The most dangerous thing for Muslims in Indonesia is democracy and the state system", and measured with dangerous world scale (Duckitt, 2001) consisting of eight items (three items omitted) for example: "Chaos and violence can happen around us anytime"

\subsection{Research Subjects}

Samples in this study were members and sympathizers of Anshoru Tauhid in Malang, Surabaya, Solo, Bima, and Jakarta; members and sympathizers of Majelis Mujahidin Indonesia in Yogyakarta, Solo, Sragen, Karanganyar and Sukoharjo; and members and sympathizers of Hizbut Tahrir Indonesia in Surabaya and Jakarta. Total number of research subjects who support the attitude toward khilafa-sharia establishment model were 384 people, with details as follows: 224 people $(69.6 \%)$ members of JAT, MMI and HTI, 22 people $(6.8 \%)$ leaders of JAT, MMI and HTI, and 76 people (23.6\%) sympathizers of JAT, MMI and HTI.

\subsection{Procedures}

Five hundred copies of questionnaire were distributed. To MMI, 150 copies were given out, 147 of it were returned completed and could be processed. To JAT, 150 copies were given out, 137 were completed. While to HTI, 200 copies were given out, 196 copies were returned but only 100 copies could be processed because 70 of it had the same exact answers and probably were filled in by one management staff in HTI Surabaya.

\section{RESULTS}

Results of confirmatory factor analysis showed that items developed to measure each variables could significantly measure the theoretical concept behind them. All items from all scales were valid, except item PDB3 from dangerous world perceptions scale and item IS3 from salafi ideology scale. Those two items were then omitted and excluded from further calculation. The results from confirmatory factor analysis model is shown in Table 1.

\begin{tabular}{lccccc}
\multicolumn{6}{c}{ TABLE 1 . Results of Confirmatory Factor Analysis } \\
\hline Variable & Reliability & Validity & RMSEA & GVI & Conclusion \\
KSE & 0.72 & 0.45 & 0.00 & 1.00 & good fit \\
NUA & 0.87 & $0.32-0.74$ & 0.069 & 0.93 & good fit \\
NTM & 0.74 & $0.45-0.87$ & 0.13 & 0.90 & marginal fit \\
SI & 0.78 & $0.50-0.79$ & 0.00 & 0.97 & good fit \\
DII & 0.71 & $0.53-0.64$ & 0.03 & 0.98 & good fit \\
GI & 0.77 & $0.32-0.83$ & 0.041 & 0.92 & good fit \\
\hline
\end{tabular}

KSE=khilafa-sharia establishment; NUA=need of uncertainty avoidance; NTM= need of threat management; $\mathrm{SI}=$ salafi ideology; DII=daula Islam ideology; GI=group identification

While results of structural test showed that khilafa-sharia establishment model that was proposed as the hypothesis, fits, which means there's a match between the model and data on HTI, JAT and MMI, meeting the qualification of: P-value $\geq 0.05$, Root Mean Square Error of Approximation (RMSEA) $\leq 0.05$, Goodness of fit index (GFI) $\geq 0.90$ and T-value $\geq 1.96$ (Byrne, 1998). So it can be said that attitude toward khilafa-sharia establishment was influenced by the need of uncertainty avoidance, need of threat management, through salafi ideologi, daula Islam ideology, and group identification.

TABLE 2. Good of fit attitude model toward khilafa-sharia establishment

\begin{tabular}{ccccccc}
\hline Group & $\chi$ & $d f$ & RMSEA & CFI & P-value & Conclusion \\
HTI & 34.41 & 28 & 0.048 & 0.99 & 0.19 & Good Fit \\
JAT & 36.86 & 28 & 0.048 & 0.96 & 0.12 & Good Fit \\
MMI & 35.11 & 28 & 0.042 & 0.98 & 0.17 & Good Fit \\
\hline
\end{tabular}

All structural relations in khilafa-sharia establishment model that were proposed in this study were significant on $p \geq 0.05$. The summary of the relations are shown more clearly in figure $2,3,4$ and 5 . 


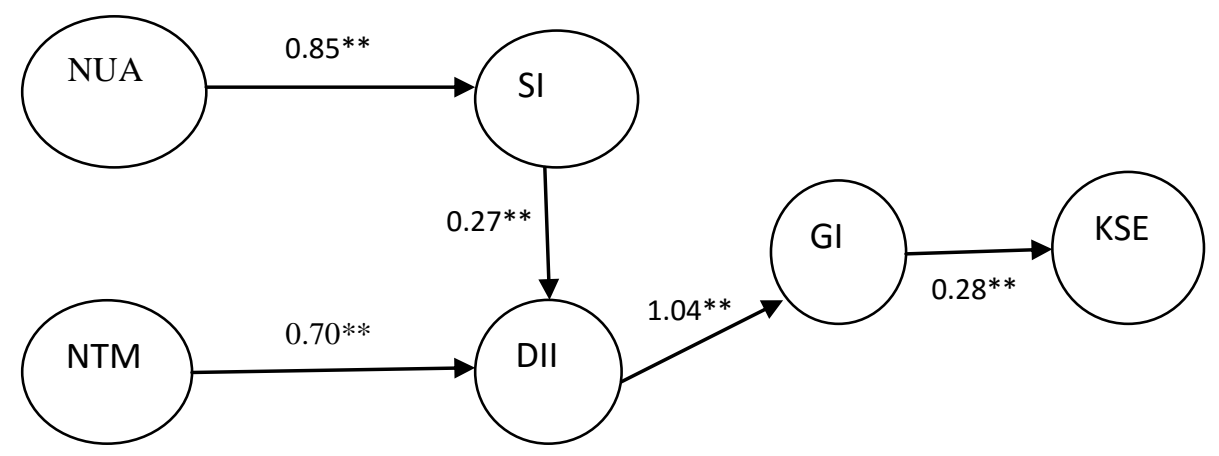

KSE=khilafa-sharia establishment; NUA=need of uncertainty avoidance;

$\mathrm{NTM}=$ need of threat management; SI=salafi ideology;

DII=daula Islam ideology; GI=group identification Significant on **p0.01

Fig 2. Relationship strength of structural equation model in HTI, JAT and MMI

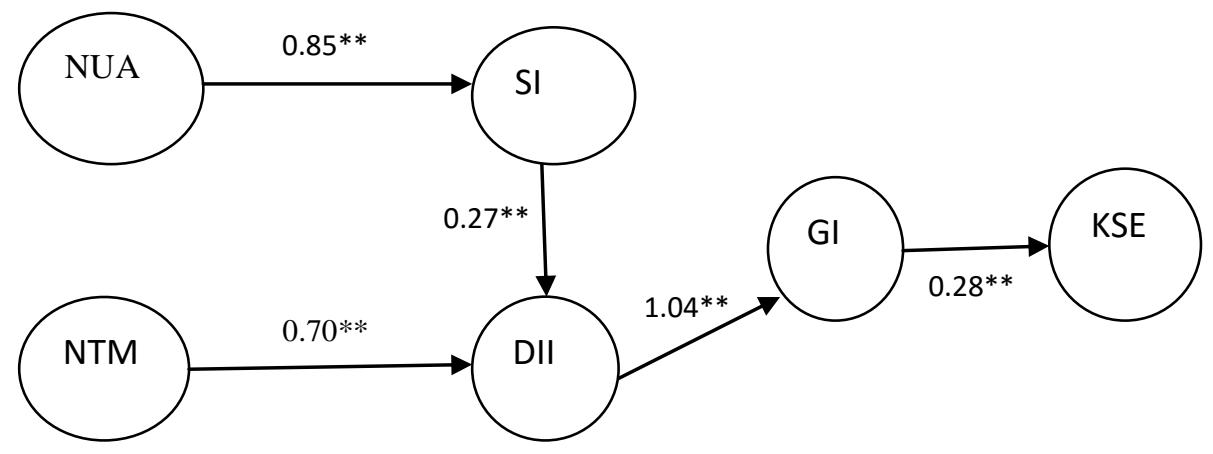

Fig 3. Relationship strength of structural equation model in HTI

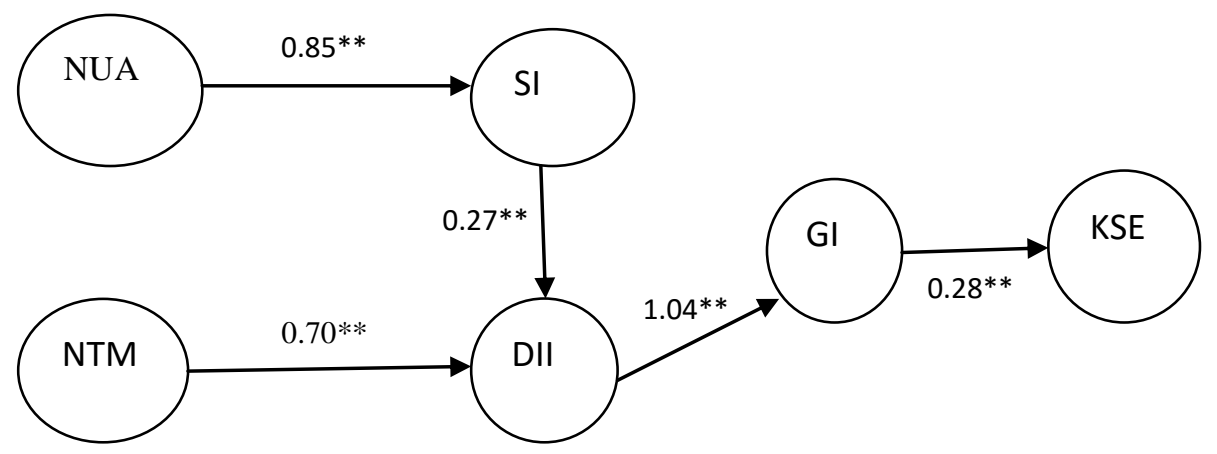

Fig 4. Relationship strength of structural equation model in JAT

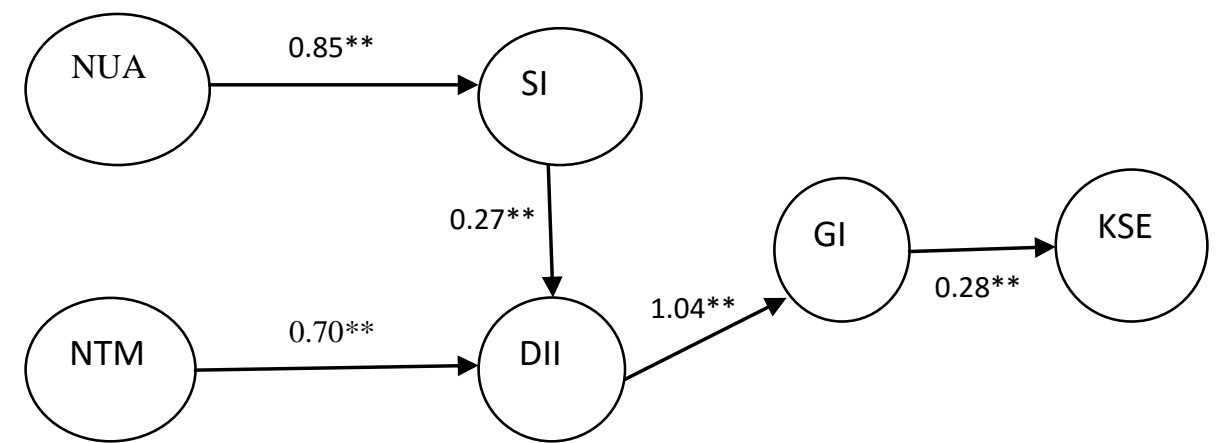

Fig 5. Relationship strength of structural equation model in MMI 
Seeing the Ss coefficient, then in three group model (HTI, JAT and MMI together), the variable directly influencing attitude toward khilafa-sharia establishment was group identification variable with coefficient Ss 0.58 . While in grouping model, HTI was with coefficient 0.28 , JAT with coefficient 0.28 , and MMI with coefficient 0.61 .

Variable coefficient with the strongest influence to the three group model was daula Islam ideology toward group identification, with Ss coefficient 0.83 . While in group model, variable coefficient with the strongest influence in HTI was the need of uncertainty avoidance variable toward salafi ideology with coefficient 0.85 ; in JAT the strongest influence was salafi ideology variable toward daula Islam ideology with coefficient 0.79; and in MMI it was daula Islam ideology variable toward group identification with coefficient 0.89 .

Another strong influence was salafi ideology variable toward daula Islam ideology, with Ss coefficient 0.73. While in group model, the variable with a strong influence in HTI was the need of threat management variable toward daula Islam ideology with coefficient 0.70 ; in JAT, it was the need of uncertainty avoidance variable toward salafi ideology with coefficient 0.65 ; and in MMI it was the need of threat management variable toward daula Islam ideology with coefficient 0.71 .

In three groups together model, the variable with the weakest influence but significant was the need of threat management toward daula Islam ideology, with Ss coefficient 0.16 . The need of uncertainty avoidance also didn't have a strong influence toward salafi ideology with coefficient Ss 0.23 . This was different with the single group model, where in HTI the variable with the weakest influence was salafi ideology variable toward daula Islam, with coefficient 0.27 , also group identication variable, that had a weak influence toward khilafasharia establishment with coefficient 0.28. In JAT, the variables with weakest influence were the need of uncertainty avoidance variable toward daula Islam ideology, with coefficient 0.27 , and group identification variable toward attitude to khilafa-sharia establishment variable, with coefficient 0.28 . While in MMI, variable with the weakest influence was salafi ideology variable toward daula Islam ideology, with coefficient 0.34.

Hypothesis testing was conducted to determine whether the hypothesis proposed in this study is accepted or rejected. The statistical significance in this study, by using t-statistic on significance level 0.05 , then $\mathrm{t}$-statistic ( $\mathrm{t}$-value) needed is $\geq \pm 1.96$. As shown in Table 3, based on the $\mathrm{t}$-value then all the hypotheses were accepted, which means all variables significantly influenced the other variables.

TABLE 3. Hypotheses test results

\begin{tabular}{cccc}
\hline \multicolumn{2}{c}{ Variable relations } & \multicolumn{2}{c}{ T-value } \\
& HTI & JAT & MMI \\
NUA and SI & 8.54 & 5.99 & 7.39 \\
NTM and DII & 3.30 & 2.09 & 5.92 \\
SI and DII & 1.37 & 5.80 & 3.30 \\
DII and GI & 8.79 & 3.21 & 4.58 \\
GI and KSE & 6.53 & 2.51 & 4.25 \\
\hline
\end{tabular}

$\mathrm{t}$ table $\geq \pm 1.96$ on significance level 0.05

\section{DISCUSSION}

The results show support to psychological needs model from attitudes toward khilafa-sharia establishment in Indonesia, both in three groups together or in each group. This finding is theoretically important, because the results are a critique toward system justification theory (Jost \& Hunyady, 2002). Political attitude to change the status quo appears not because of political ideology (liberal-conservative), but due to strong psychological needs, Islamic political ideologies, and group identification.

This study reveals that the need of uncertainty avoidance and the need of threat management are pychological forces underlying ideology and political behaviors (Josh et al., 2003a). The dichotomy about muslims-infidels along with the view of Islam as absolutely right, and anything other than Islam as absolutely wrong, show a high tendency in individuals to have certainty and stability in their social life (Van den Bos, 2009). A high need of uncertainty avoidance drives them to purify Islam and live in the way of life of the past.

Individuals who have this need will hold salafi ideology, which is the belief to purify the religion and live according to the ways of the salaf. They want to practice Islam as perfectly as the Prophet Muhammad's teachings. Psychologically, it can be explained that when individuals or groups think about situations that make them uncertain, they will obey the cultural norms and values (Van den Bos et.al., 2005). This is because the view to live in Islamic ways as the original teachings of the Prophet serves to provide certainty and stability.

While the need of threat management stems from secular-democracy system which separates religion from state, and this secular ideology threatens the purity of Islam. The curent condition of the world and secular ways of living are seen as a threat toward the purity of the teachings of Prophet Muhammad (Sageman, 2004). 
Norms, beliefs and symbols of secular-democracy are forbidden systems which threatens pure Islamic teachings, contrary to Islamic values and identity, and cause fear that secular culture will get rid of Islamic way of life.

Secular-democracy threatens the religion, values, belief system, ideology, philosophy, morality or worldview of muslims. The ideal about practicing Islam in a perfect and pure way as in the time of salaf can only be achieved within daula Islam. The need of threat management drives individuals and groups to hold daula Islam ideology, which is the belief about the importance of establishing daula Islam in regulating Islamic society. This study also support "the uncertainty paradox" (Haas \& Cunningham, 2014), when individual or group feel save, uncertainty leads to greater tolerance, yet when threatened, uncertainty leads to reduce tolerance.

For political Islamic groups, what matters for muslims is only khilafa (Islamic power). Purifying the religion and re-managing individual behaviors and the muslim community have to be based on Islam (Frey, 2007), by applying sharia in all aspects of life with force. This can only be achieved by having control on political powers (An-Naim, 2003). Each muslim has the obligation to participate in developing khilafa and sharia through relatively homogeneous group, an entity that is based on commitment to faith and salafi ideology system and daula Islam (see Hogg, 2004).

This phenomenon of change initiated by the right-wing is called as "conservative paradox" by Jost et. al. (2003b), which is changes in current time by taking idealism of the past. Because according to system justification theory (Jost \& Hunyady, 2002), individuals with conservative ideology will reject changes. This idea by Jost was rejected by Greendberg and Jonas (2003), who argued that even if they idealize the past, they still encourage change. The attitude of political Islamic groups in Indonesia in changing the democracy system to khilafa-sharia is their reaction that is based on certain religious interpretations, by taking visions of the past to strengthen the present and build the future.

\section{CONCLUSION}

A high need of uncertainty avoidance influences the level of salafi ideology. While perceived threats toward religious beliefs drive groups to hold daula Islam ideology. Strong daula Islam ideology eventually becomes the group identity, which strengthens identification toward political Islamic groups and therefore strengthens their commitment to achieve their goal, which is to replace democracy in Indonesia with khilafa and sharia. These groups want to return to muslim glory by going back to Islamic teachings, which means that all the aspects of social, economic, and political life are based exclusively on Islam using the khilafa and sharia system. Islam's glory can be achieved by returning to the original doctrines of the Prophet. The roles of political Islamic ideologies that are driven by a high need of uncertainty avoidance and threat management through group identification to attitude toward khilafa-sharia establishment are discussed.

Based on the results of this study, we learn that political Islamic groups have a high need of uncertainty avoidance and threat management. These two needs are fulfilled by salafi ideology and daula Islam ideology, that are disseminated in the group and strengthen the identification to Islamic groups. The results of this study give two practical and theoretical suggestions. For the practical suggestion, considering that the roles of the group and the leaders are very important, then to deal with the problem of khilafa-sharia establishment attitude, it is suggested to address it at the group level. Changing this attitude is not a simple task, taking into account that behind the attitude there are very strong psychological needs and Islamic political ideologies. But it can still be done through communication, discussions or debates using the language of the Quran and hadith between leaders/ulema who support sharia and leaders/ulema who support democracy. The results of the discussions should be widely disseminated to society. Even if these discussions cannot change their ideology, this needs to be considered, like the discussions between Sunni and Shia muslims that have already been made into a book. For theoretical suggestion, we suggest to test the model using a wider sample, be it from other khilafa-sharia supporter groups or mainstream muslim groups.

\section{REFERENCES}

[1] Adorno, T., Frenkel-Bruswik, E., Levinson, D., \& Stanford, N. (1950). The Authoritarian Personality, New York: Harper.

[2] Almond, G.A., Appleby, R.S., \& Sivan, E. (2003) Strong Religion: The Rise of Fundamentalisms around the World. Chicago: University of Chicago Press.

[3] AnNaim, A. A. (2003). Islamic fundamentalism and social change: Neither the 'end of history' nor a clash of civilizations'. Dalam The freedom to do Good's will: Religious fundamentalism and social change. Diedit oleh Harr, Gerrie ter dan Busuttil, J.J. London: Routledge.

[4] Ashour, O. (2009). Votes and violence: Islamists and the processes of transformation. London. www.icsr.info 
[5] Ben Ali, M. (2006). Ideological respon to terrorism and extremism: Case study of jemaah Islamiyah (JI). Paper dipresentasikan di $1^{\text {st }}$ Convention of Asian Psychological Association, pada tanggal 18-20 agustus 2006 di Kuta, Bali, Indonesia.

[6] Budner, S. (1962). Intolerance of ambiguity as a personality variable. Journal of Personality, 30, $29-59$.

[7] Byrne B. M. (1998). Structural Equation Modeling with LISREL, PRELIS, and SIMPLIS: Basic Concept, Application, and Programming. New Jersey: Lawrence Erlbaum Associates Publishers.

[8] Cadinu, M. \& Reggiori, C. (2002). Discrimination of a low status outgroup: the role of ingroup threat. European Journal of Social Psychology, 32, 501-515.

[9] Cusniyah, T. (2012). Model sikap terhadap penegakan khilafah-syariah di Indonesia. Jurnal Insan: Media psikologi. Vol.14, No. 2, Agustus 2012.

[10] Duckitt, J. (2001). A dual-process cognitive-motivational theory of ideology and prejudice. Advances in Experimental Social Psychology, 33, 41-113.

[11] Effendy, B. (1998). Islam dan Negara: Transformasi Pemikiran dan Praktik Politik Islam di Indonesia. Jakarta: Paramadina.

[12] Esposito, J. \& Voll, J. (2001). Makers of Contemporary Islam. New York: Oxford University Press.

[13] Frey, R. J. (2007). Global issue: Fundamentalism. New York: Infobase Publishing.

[14] Frenkel-Brunswick, E. (1947). A study of prejudice in children. Human Relation. 1, 3.

[15] Golose, P.R. (2010). Evolusi dan transformasi terorisme di Indonesia. Paper yang disampaikan dalam simposium nasional:"Memutus mata rantai radikalisme dan terorisme" pada 27-28 Juli 2010, di hotel Le Meridian, Jakarta.

[16] Greenberg, J. \& Jonas, E. (2003). Psychological motives and political orientation-the left, right, and the rigid: comment to Jost at. al. (2003). Psychological Bulletin, Vol. 129, No. 3, 376-382.

[17] Hass \& Cunningham (2014). The uncertainty paradox: Perceive threat moderates the effect of uncertainty on political tolerance. Political psychology. Vol. 35, N0. 2, 291-302.

[18] Hasan, N. (2008). Lasykar Jihad: Islam, militansi dan pencarian Identitas di Indonesia paska Orde Baru. Jakarta: Pustaka LP3ES Indonesia \& KITLV-

[19] Hogg, M.A. (2004). Uncertainty and extremism: Identification with high entitativity groups under conditions of uncertainty. In V. Yzerbyt, C.M. Judd \& O. Corneille (Eds.), The Psychology of group perception: Perceived variability, entitativity, and essentialism, 401-418. New York: Psychology Press.

[20] Jost, J. T, (2006). The End of the End of Ideology. American Psychologist, Vol. 61, No. 7, 651-670.

[21] Jost, J. T., Banaji, M. R., \& Nosek, B. A. (2004). A Decade of system justification theory: Accumulated evidence of conscious and unconscious bolstering of the status quo. Political Psychology, Vol.25, No.6, 881-919.

[22] Jost, J. T., Glaser, J., Kruglanski, A. W., \& Sulloway, F (2003a). Political conservatism as motivated social cognition. Psychological Bulletin, 129, 339-375.

[23] Jost, J. T., Glaser, J., Kruglanski, A. W., \& Sulloway, F (2003b). Exception that prove the rule-using theory of motivated social cognition to account for ideological incongruities and Political anomalies: Reply to Greenberg and Jonas (2003). Psychological Bulletin, 129, 383-393.

[24] Jost, J. T. \& Hunyady, 0. (2005). Antecedents and concequences of system justifying ideologies. European Review of Social Psychology, 13, 111-153.

[25] Jost, J. T., \& Hunyady, 0. (2002). The psychology of system justification and the palliative function of ideology. European Review of Social Psychology, 13, 111-153.

[26] Jost, J. T., Nosek, B. A. \& Gosling, S. D. (2008). Ideology: Its resurgence in social, personality, and political psychology. Current Directions in Psychological Science, Vol 14(5), 206-265.

[27] Kenny, D. A. (1979). Corelation and causality. New York: John Willey.

[28] Kerlinger, F. N. (1984). Liberalism and conservatism: The nature and structure of social attitudes. Hillsdale, NJ: Erlbaum.

[29] Kerlinger, F. N. (2000). Asas-asas Penelitian Behavioral. Penerjemah Simatupang L. R. \& Kusmanto, H. J., Yogyakarta: Gajahmada University Press.

[30] Kompas.com (2011). Vonis Ba'asyir: Pengadilan Gagal Ungkap Motif Ba'asyir Liu, H. dan Inggried. http://nasional.kompas.com. Diunduh pada 29 Desember 2011.

[31] Kramer, M. (2003). The moral logic of Hizballah. In Origin of Terrorism: Psychologies, Ideologies, Theologies, State of Mind. Edited by Reich, W.; Washington. D. C.: The Woodrow Wilson Center Press.

[32] Kruglanski, A. W. \& Fishman, S. (2009). Psychological factors in terrorism and counterterrorism: Individual, group, and organizational levels of analysis. Social issues and policy review, 3 (1).

[33] Lane, S. T. M. (1999). Ideology and consciuosness. Theory \& Psychology, Vol. 9(3), 367-378.

[34] Madrid, R. (2001). Fundamentalis and democracy: The politic culture of Indonesian Islamist students. Dissertation. UMI. American University. 
[35] McCrae, R. R. (1996). Social consequences of experiential openness. Psychological Bulletin, 120, 323337.

[36] Moaddel, M. \& Karabenick, S.A. (2008). Religious Fundamentalism among Young Muslims in Egypt and Saudi Arabia. Social Forces, Volume 86, Number 4.

[37] Mujani, S. (2003). Religious Democrats: Democratic Culture and Muslim Political Participation in Post Suharto Indonesia. A Dissertation submitted in partial fulfillment of requirement for the degree of doctor of philosophy in political science at the Ohio State University.

[38] Muluk, H., \& Sumaktoyo, N.G. (2010). Intratextual fundamentalism and the desire for simple cognitive structure: The moderating effect of the ability to achieve cognitive structure. Archive for the Psychology of Religion, 32, 1-22.

[39] Purnomo, A. (2004). FPI Disalahfahami. Jakarta: Mediatama Indonesia.

[40] Ramakrishna, K. (2009). Radical pathways: Understanding muslim radicalization in Indonesia. London: Praeger Security International.

[41] Ramleth, A. H. (2001). Manufacturing A New Islamic Order: Islamic Discourse in Ujung Pandang (Makassar), South Sulawesi, Indonesia. A Dissertation submitted in partial fulfillment of requirement for the degree of doctor of philosophy in anthropology at University of Washington.

[42] Rappoport, D. (1998). Sacred terror: a contemporary example from Islam. Origin of Terrorism: Psychologies, Ideologies, Theologies, State of Mind. Edited by Reich, W. ;Washington. D. C.: The Woodrow Wilson Center Press.

[43] Rokeach, M. (1968). Beliefs, attitudes, and values. San Francisco: Jossey- Bass.

[44] Sageman, M. (2004). Understanding Terror Network. Philadelphia: University of Pennsylvania Press.

[45] Sheridan, M. (2006). Sunday times. 30 July.

[46] Thorisdottir, H.; Jost, J. T. and Kay, A. C. (2009). On the Social and Psychological Bases of Ideology and System Justification. Dalam Social and Psychological Bases of Ideology and System Justification. Diedit oleh Edited by John T. Jost, Aaron C. Kay, and Hulda Thorisdottir. New York: Oxford University Press.

[47] Unger, R. K. (2002), Them and Us: Hidden Ideologies-Differences in Degree or Kind?. Analyses of Social Issues and Public Policy, 2, 43-52.

[48] Van den Boss, K. (2009). The Social psychology of uncertainty management and system justification. Dalam Social and Psychological Bases of Ideology and System Justification. Diedit oleh Edited by John T. Jost, Aaron C. Kay, and Hulda Thorisdottir. New York: Oxford University Press.

[49] Van den Bos, K., Poortvliet, P. M., Maas, M., Miedema, J., \& van den Ham, E. (2005). An enquiry concerning the principles of cultural norms and values: The impact of uncertainty and mortality salience on reactions to violations and bolstering of cultural worldviews. Journal of experimental social psychology, 42, 910133.

[50] Zada, K. (2003). Politik Islam radikal: Survei wacana dan gerakan Islam di Indonesia. Jurnal Demokrasi dan HAM, 3, 1, Januari-April. 